\title{
PUTUSAN MAHKAMAH KONSTITUSI ATAS PENDAPAT DPR RI MENGENAI IMPEACHMENT PRESIDEN DAN/ATAU WAKIL PRESIDEN
}

\author{
Moh. Saleh \\ Fakultas Hukum Universitas Narotama Surabaya \\ Jl. Arief Rahman Hakim 51 Surabaya
}

\begin{abstract}
Abstrak
Mahkamah Konstitusi memiliki wewenang untuk mengadili pada tingkat pertama dan terakhir dan putusannya bersifat final dan mengikat sejak putusan tersebut dibacakan dalam sidang pleno terbuka untuk umum. Di sisi lain, wewenang melakukan impeachment terhadap Presiden dan/atau Wakil Presiden adalah wewenang Dewan Perwakilan Rakyat sedangkan Mahkamah Konstitusi berwenang untuk mengkontrol proses impeachment terhadap Presiden dan/atau Wakil Presiden yang dipilih secara langsung oleh rakyat.
\end{abstract}

Kata Kunci: impeachment, mengikat, Putusan MK

\begin{abstract}
Constitutional Court has a jurisdiction in the first process and latest which its decision will be considered as a final decision (Article 24C point 1 of Third Amendment Indonesian Constitution 1945) and legally binding since the decision has been made in an opening court for public (Article 47 Constitutional Court Act).In the other side, the impeachment right of the President and his Second in Command is the main jurisdiction of High House of Representatives (Article 3 point 3 Third Amendment of Indonesian Constitution 1945). While one of the main ideas of the exsistence of Constitutional Court in Indonesia is becoming a tool of judicial control in the impeachment process of President and/or vice President, which they have been elected directly by people.
\end{abstract}

Keywords: impeachment, legally binding, constitutional court's decision. 


\section{A. PENDAHULUAN}

Mahkamah Konstitusi merupakan salah satu pelaku kekuasaan kehakiman sebagaimana dimaksud dalam UUD NRI 1945. ${ }^{1}$ Keberadaan MK di dalam kekuasaan kehakiman Indonesia adalah sebagai penjaga konstitusi (the guardian of the constitution atau waakhond van de grondwet), sehingga kewenangan yang diberikan oleh UUD NRI 1945 kepada MK tersebut adalah untuk menyelesaikan terjadinya pelanggaran terhadap hak-hak konstitusional ${ }^{2}$.

Adapun kewenangan MK tersebut adalah sebagaimana terdapat di dalam Pasal 24C ayat (1) Amandemen ketiga UUD NRI 1945 yang berbunyi :

Mahkamah Konstitusi berwenang mengadili pada tingkat pertama dan terakhir yang putusannya bersifat final untuk menguji undang-undang terhadap undang-undang dasar, memutus sengketa kewenangan lembaga negara yang kewenangannya diberikan oleh Undang-Undang Dasar, memutus pembubaran partai politik, dan memutus perselisihan tentang hasil pemilihan umum.

Selain keempat kewenangan tersebut, MK juga mempunyai satu kewajiban untuk memeriksa, mengadili dan memutus terhadap pendapat DPR mengenai dugaan adanya pelanggaran hukum yang dilakukan oleh Presiden dan/atau Wakil Presiden. Hal ini sebagaimana terdapat di dalam Pasal 24C ayat (2) Amandemen ketiga UUD NRI 1945 yaitu: "Mahkamah Konstitusi wajib memberikan putusan atas pendapat Dewan Perwakilan Rakyat mengenai dugaan pelanggaran oleh Presiden dan/atau Wakil Presiden menurut Undang-Undang Dasar".

Kewenangan dan kewajiban MK ini didasarkan atas gagasan checks and balances dalam bentuk control judicial yang dilakukan oleh MK, karena salah satu asas dari negara hukum (rechtstaat) adalah adanya peran peradilan yang bebas dan tidak memihak untuk memberikan putusan terhadap segala kasus hukum yang terjadi di dalam suatu negara. Dengan demikian, Indonesia sebagai negara hukum harus menyelesaikan segala persoalan hukum melalui proses hukum, termasuk proses impeachment ${ }^{3}$ Presiden dan/atau Wakil Presiden ${ }^{4}$.

\footnotetext{
${ }^{1}$ Pasal 1 angka 1 UU MK

${ }^{2}$ Pasal 51 ayat (1) UU MK

${ }^{3}$ Impeachment adalah pemanggilan atau pendakwaan untuk meminta pertanggungjawaban atas persangkaan pelanggaran hukum yang dilakukan dalam masa jabatannya. Abdul Rosyid Thalib,
} 
Melalui Amandemen Ketiga UUD NRI 1945, bahwa kedudukan MPR dan Presiden telah sejajar serta Presiden dan Wakil Presiden tidak lagi dipilih melalui MPR, tetapi dipilih langsung oleh rakyat melalui pemilihan umum. Dengan demikian, MPR tidak lagi berwenang menjatuhkan Presiden dan/atau Wakil Presiden atas dugaan melakukan pelanggaran hukum berdasarkan pengajuan DPR tanpa melalui dasar dan proses hukum dari lembaga yudisial yang berwenang (dalam hal ini yaitu MK).

Jika dugaan adanya pelanggaran hukum oleh Presiden dan/atau Wakil Presiden an sich diselesaikan melalui proses politik di dalam rapat paripurna DPR maupun MPR, maka akan terjadi proses impeachment Presiden dan/atau Wakil Presiden tersebut atas dasar kepentingan politik DPR dan MPR, meskipun pada dasarnya Presiden dan/atau Wakil Presiden tersebut tidak melakukan pelanggaran hukum.

Namun demikian, adanya keterlibatan hukum di dalam proses impeachment Presiden dan/atau Wakil Presiden tersebut masih menimbulkan persoalan hukum. Mengingat "putusan"5 MK atas pendapat DPR mengenai dugaan melakukan pelanggaran hukum oleh Presiden dan/atau Wakil Presiden tersebut masih harus diputuskan di dalam rapat paripurna MPR atas usul pemberhentian yang diajukan oleh DPR. Hal ini memang "Putusan" MK tersebut hanya sebatas melaksanakan kewajiban konstitusi atas permintaan DPR, artinya "putusan" yang dikeluarkan oleh MK pada dasarnya bukan melaksanakan wewenang MK, tetapi hanya melaksanakan kewajiban konstitusional.

Berdasarkan ketentuan konstitusional di dalam Pasal 2 ayat (3) Amandemen ketiga UUD NRI 1945 bahwa wewenang untuk memberhentikan Presiden dan/atau Wakil Presiden tersebut berada pada MPR yang diatur menurut UUD

Wewenang Mahkamah Konstitusi dan Implikasinya dalam Sistem Ketatanegaraan Republik Indonesia, Bandung: PT. Citra Aditya Bakti, 2006, hlm. 453.

${ }^{4}$ Presiden merupakan pemegang kekuasaan pemerintahan di dalam Negara Kesatuan Republik Indonesia menurut UUD NRI 1945 [(Pasal 4 ayat (1) UUD NRI 1945)]. Wakil Presiden adalah pembantu Presiden dalam melaksanakan kewajibannya. Hal ini sesuai Pasal 4 ayat (2) UUD NRI 1945 bahwa dalam melakukan kewajibannya Presiden dibantu oleh satu orang Wakil Presiden.

${ }^{5}$ Putusan merupakan suatu pernyataan akhir dari para Hakim Konstitusi MK sebagai hasil dari proses memeriksa dan mengadili atas pendapat DPR mengenai dugaan pelanggaran oleh Presiden dan/atau Wakil Presiden [(Pasal 24C ayat (2) Amandemen ketiga UUD NRI 1945)]. 
NRI 1945. Dengan demikian, MK sebenarnya bukanlah lembaga negara yang berwenang untuk memberhentikan terhadap Presiden dan/atau Wakil Presiden dalam masa jabatannya.

Namun demikian, MK adalah merupakan institusi peradilan, dimana setiap putusannnya mempunyai kekuatan mengikat sejak putusan MK tersebut telah dinyatakan mempunyai kekuatan hukum tetap (in kracht van gewijsde). Hal ini sebagaimana diatur di dalam Pasal 47 UUMK yang berbunyi: "Putusan Mahkamah Konstitusi memperoleh kekuatan hukum tetap sejak selesai diucapkan dalam sidang pleno terbuka untuk umum".

Sejak diucapkan dalam sidang pleno yang terbuka untuk umum, putusan itu secara serta merta telah mempunyai kekuatan mengikat. Adapun yang dimaksud dengan telah mempunyai kekuatan mengikat adalah putusan MK tersebut langsung dapat dilaksanakan dengan tidak memerlukan lagi keputusan dari pejabat atau lembaga lain. ${ }^{6}$

Dengan demikian terdapat dua fakta hukum yang berbeda di atas, yaitu di satu sisi putusan MK itu bersifat final atau mempunyai kekuatan hukum tetap (in kracht van gewijsde), akan tetapi di sisi lain putusan MK itu tidak secara merta merta dapat dilaksanakan karena harus melalui proses politik terlebih dahulu di dalam rapat paripurna MPR. Berdasarkan latar belakang itulah dirumuskan dua rumusan masalah berikut ini:

1. Apakah Putusan MK mempunyai kekuatan hukum mengikat dalam proses impeachment Presiden dan/atau wakil Presiden?

2. Bagaimanakah dampak konstitusional Putusan MK terhadap Keputusan DPR maupun MPR dalam proses impeachment Presiden dan/atau Wakil Presiden?

\footnotetext{
${ }^{6}$ Putusan MK ini bersifat publik sehingga putusannya tersebut mempunyai kekuatan hukum mengikat bukan hanya terhadap para pihak (interparties), tetapi juga harus ditaati oleh siapapun (orga omnes). Bambang Sutiyoso, Hukum Acara Mahkamah Konstitusi Republik Indonesia, Bandung: PT. Citra Aditya Bakti, 2006, hlm. 43-44.
} 


\section{B. PUTUSAN MAHKAMAH KONSTITUSI DALAM PROSES IMPEACHMENT PRESIDEN DAN/ATAU WAKIL PRESIDEN}

\section{Proses Impeachment Presiden dan/atau Wakil Presiden di Beberapa Negara}

Impeachment pada dasarnya bukan hanya merupakan proses pemberhentian Presiden dan/atau Wakil Presiden dalam sama jabatannya, tetapi impeachment tersebut merupakan proses pemberhentian terhadap para pejabat negara yang dianggap melanggar ketentuan sebagaimana telah diatur di dalam peraturan perundang-undangan.

Menurut teori hukum tata negara terdapat dua cara impeachment. Pertama, cara impeachment di tengah masa jabatannya yang dilakukan oleh legislatif. Kedua, impeachment melalui mekanisme forum pengadilan khusus (special legal proceeding) atau forum privelegiatum (forum peradilan khusus diadakan untuk itu). ${ }^{7}$

Cara yang pertama, menurut Harjono, impeachment lahir pada zaman Mesir kuno dengan istilah iesamhelia, artinya kecenderungan ke arah pengasingan diri yang pada abad ke-17 diadopsi pemerintahan Inggris dan oleh negara Amerika Serikat dimasukkan ke dalam Konstitusi pada akhir abad ke18.

Impeachment di Amerika Serikat dilakukan terhadap Presiden dengan alasan telah melakukan pengkhianatan (treason), penyuapan (bribery), tindak pidana ringan (misdemeanors), melakukan kejahatan terhadap orang lain (other hight crimes). Menurut I Dewa Gede Atmadja dan dipertegas oleh Moh. Fajrul Falakh, impeachment di Amerika Serikat lebih bersifat yuridis pidana karena melalui mekanisme yang menyerupai jalannya suatu kasus di pengadilan. Pada tingkat awal House of representatives berfungsi sebagai penuntut umum yang ditujukan kepada Presiden dan selanjutnya disidangkan di Senate yang dipimpin oleh ketua Supreme Court (Mahkamah Agung), kemudian dakwaan itu dibahas dan diputus. Sedangkan proses pengambilan keputusan suara di

${ }^{7}$ Abdul Rasyid Thalib, Op. cit., hlm. $23-24$. 
senat untuk memvonis pemberhentian Presiden, harus dihadiri oleh 2/3 (dua pertiga) anggota Senat, dan 2/3 (dua pertiga) yang hadir harus menyetujuinya. ${ }^{8}$

Meskipun aturan Impeachment telah jelas, tetapi Impeachment terhadap Presiden Amerika Serikat belum pernah terjadi. Presiden Richard Nixon dalam kasus Watergate (penyadapan telepon di kantor Partai Demokrat) mengundurkan diri sebelum sidang dilaksanakan oleh Senat dan digantikan oleh Wakil Presiden Gerard Ford. Dua Presiden lainnya, Andrew Johnson (1865 - 1869), Bill Clinton (1993 - 2001) tidak berhasil diberhentikan karena tidak mendapat persetujuan 2/3 (dua pertiga) anggota Senat yang hadir. ${ }^{9}$

Kelemahan cara impeachment ini adalah jika dalam forum legislatif Presiden diberhentikan, tetapi dalam proses hukumnya Presiden dinyatakan tidak bersalah adalah sulit mengembalikan jabatan Presiden karena realitas politik telah berubah dengan terpilihnya Presiden yang baru. Hal ini dapat dilihat ketika Gerard Ford menggantikan Richard Nixon ketika hendak diadili, barang bukti penyadapan itu kurang dapat dipertanggungjawabkan. Selanjutnya Gerard Ford mengeluarkan keputusan pengampunan Richard Nixon dan peradilan Pidana dihentikan. ${ }^{10}$

Menurut konstitusi Jerman, ketentuan mengenai Proses impeachment diatur di dalam Bab V Pasal 61 mengnai Presiden. Di dalam Pasal 61 ayat (1) ditentukan bahwa: "Impeachment terhadap Presiden dapat diajukan oleh 1/4 anggota Bundestag (House of Representatives) atau 1/4 jumlah suara dalam Bundesrat (Senate)".

Berdasarkan ketentuan ayat tersebut di atas bahwa impeachment dilakukan oleh parlemen hanya terhadap Presiden. Sidang impeachment dilakukan oleh Bundestag dan Bundesrat di depan MK yang akan memeriksa dan memutuskan apakah Presiden benar-benar melanggarar konstitusi atau undang-undang federal lainnya. Sedangkan wewenang untuk melakukan impeachment terhadap Presiden tersebut adalah menjadi wewenang Parlemen Jerman dengan dapat ditetapkan apabila disetujui oleh sedikitnya 2/3 anggota Bundestag dan 2/3

\footnotetext{
${ }^{8}$ Ibid., hlm. $24-25$.

${ }^{9}$ Ibid., hlm. 25.

${ }^{10}$ Ibid.
} 
anggota Bundesrat. Keputusan parlemen tersebut hanyalah keputusan politis saja sementara keputusan hukumnya dilakukan oleh MK. Sehingga apabila keputusan parlemen berbeda dengan putusan MK, maka MK diberi instrument hukum untuk secara administratif memberhentikan presiden dari jabatannya dan secara efektif membekukan fungsi kepresidenan ${ }^{11}$. Hal ini sebagaimana diatur di dalam Pasal 61 ayat (2) konstitusi Jerman yang memuat ketentuan bahwa bila Mahkamah Konstitusi memutuskan presiden bersalah telah melanggar konstitusi atau undang-undang federal lainnya, Mahkamah Konstitusi dapat menyatakan presiden telah dicopot dari jabatannya. Setelah impeachment, mahkamah Konstitusi dapat mengeluarkan perintah pengadilan interim untuk mencegah presiden menjalankan fungsi kepresidenannya.

Berdasarkan ketentuan tersebut, meskipun kewenangan impeachment berada pada parlemen tetapi keputusan parlemen tersebut harus sama dengan hasil putusan MK, jika keputusan parlemen tersebut tidak sama dengan putusan MK, maka MK dengan wewenangnya dapat memberhentikan presiden secara administratif. Dengan demikian, putusan MK tersebut mempunyai kekuatan hukum mengikat untuk dilaksanakan oleh parlemen. Atau dengan kata lain , putusan hukum dari MK tersebut mempunyai kedudukan yang lebih tinggi dari pada keputusan politik yang dikeluarkan oleh parlemen.

Cara impeachment yang kedua, adalah cara impeachment melalui special legal proceeding atau forum privelegiatum, yaitu cara pemberhentian dengan melalui proses pengadilan khusus, bukan mekanisme melalui legiflatif. Mekanisme peradilan ini dipercepat tanpa melalui jenjang pemeriksaan pengadilan konvensional dari tingkat bawah. Pengadilan ini merupakan tingkat pertama dan terakhir, serta putusannya bersifat final. Di dalam konstitusi Perancis, Presiden dan para pejabat pemerintah dapat dituntut untuk diberhentikan melalui forum pengadilan MA karena melakukan pengkhianatan terhadap negara, melakukan kejahatan kriminal, dan tindakan tidak pantas. ${ }^{12}$

${ }^{11}$ Ibid., hlm. $259-260$.

${ }^{12}$ Ibid., hlm. 27. 
Sedangkan perkara impeachment Korea Selatan diatur di dalam Bab IV bagian kedua Pasal 49 ayat (1) dan ayat (2) dan Pasal 50 serta Pasal 51 Undang-Undang Mahkamah Konstitusi, yakni:

Pasal 49:

(1) Untuk persidangan impeachment, Ketua Komite Perundang-undangan dan kehakiman dalam Majelis Nasional bertindak sebagai penuntut dalam sidang impeachment;

(2) Penuntut dalam sidang impeachment mengajukan permintaan peradilan dengan mengajukan kepada Mahkamah Konstitusi berkas tuntutan tertulis lembaga yang meng-impeach, dan dapat menanyakan terdakwa dalam persidangan verbal.

Pasal 50: "Seseorang yang tengah dituntut untuk di-impeach oleh lembaga yang meng-impeach, dapat menjalankan tugas dan kewenangannya sampai Mahkamah Konstitusi menjatuhkan putusannya atas kasus tersebut."

Pasal 51: "Bila pada saat yang bersamaan persidangan kasus tindak pidana kriminal yang sama dengan penyebab tuntutan impeachment sedang berjalan, maka Mahkamah Konstitusi dengan keputusan seluruh anggota hakim Mahkamah konstitusi dapat menunda sidang impeachment."

Berdasarkan ketentuan Pasal di atas bahwa impeachment di Korea Selatan dilakukan bukan hanya terhadap Presiden, tetapi juga terhadap para pejabat tinggi negara lainnya. Sedangkan yang menjadi objek impeachment adalah meliputi Presiden, Perdana Menteri, Anggota Dewan Negara, Kepala Kementerian Eksekutif, Hakim Mahkamah Konstitusi, Hakim, Anggota Komisi Pemilihan Umum, Ketua dan Anggota Badan Audit dan inspeksi, serta pejabat publik lain yang ditugaskan berdasarkan undang-undang yang relevan [(Pasal 65 ayat (1) dan Pasal 113 ayat (2) Undang-Undang Mahkamah Konstitusi Korea Selatan)].

Berdasarkan ketentuan di dalam konstitusi Korea selatan bahwa yang mempunyai wewenang untuk melakukan impeachment terhadap para pejabat tinggi negara adalah MK (Pasal 111 ayat (1) sub 2). Sedangkan Majelis 
Nasional (national assembly) hanyalah sebagai penuntut dan membuat dakwaan untuk diajukan kepada MK (Pasal 65 ayat (1)).

Impeachment di Korea Selatan memberikan kewenangan kepada Majelis nasional untuk membuat tuntutan dan dakwaan serta meminta proses pemidanaan dilakukan oleh MK. Impeachment di Korea Selatan menurut sifatnya bukan merupakan pengaduan pidana, melainkan merupakan pengaduan disiplin. Akan tetapi, permintaan pertanggungjawaban Presiden atas dugaan atau tuduhan melakukan tindak pidana tertentu menjadi kewenangan MK. Jika Presiden terbukti, maka MK memberhentikan presiden dari jabatannya. Pemberhentian presiden menurut kontitusi Korea Selatan diusulkan oleh 159 anggota Majelis Nasional dari 273 jumlah keseluruhan anggota Majelis Nasional. Jika sudah mencapai 159 anggota tersebut, maka dalam waktu 24 jam setelah mosi tidak percaya diajukan ke Majelis Nasional, Majelis Nasional harus melakukan persidangan dan voting setelah 72 jam sesudahnya. ${ }^{13}$

Jika impeachment mendapat dukungan 2/3 suara dari angota Majelis Nasional, maka Majelis Nasional tersebut dapat mengeluarkan keputusan tentang pemberhentian presiden dari jabatannya. Kemudian hasil impeachment tersebut diajukan ke MK. Jika putusan MK sama dengan keputusan Majelis Nasional Korea Selatan, maka presiden secara hukum telah dinyatakan berhenti dari jabatannya sebagai presiden. Sejak pemberhentian diumumkan, maka presiden atau pejabat tinggi negara tersebut tidak diperbolehkan memegang jabatan selama lima tahun. Akan tetapi, jika putusan MK menyatakan membatalkan keputusan impeachment dari Majelis Nasional Korea Selatan, maka presiden masih tetap bisa menjabat sebaga presiden sampai masa jabatannya selesai. Proses impeachment di Korea Selatan hanya didasarkan pada pertimbangan hukum, bukan pertimbangan politik. ${ }^{14}$

${ }^{13}$ Ibid., hlm. $270-272$.

${ }^{14}$ Ibid., hlm. $269-271$. 


\section{Kekuatan Hukum Mengikat Putusan MK dalam Proses Impeachment Presiden dan/atau Wakil Presiden}

Putusan adalah hakikat peradilan, inti dan tujuan dari segala kegiatan atau proses peradilan, memuat penyelesaian perkara yang sejak proses bermula telah membebani para pihak. Kata putusan hanya lazim dipadankan dengan kata von'nis dari bahasa Belanda dan judgement dari bahasa Inggris. Menurut N.E. Algra et al., von'nis adalah keputusan yang diberikan oleh hakim untuk mengakhiri perkara yang dibawa kehadapannya dalam bentuk yang disyaratkan. Sedangkan judgement adalah keputusan hakim atau pengadilan (decision a judge or court). Sedangkan Sudikno Mertokusumo mendefinisikan putusan hakim adalah: "suatu pernyataan yang oleh hakim, sebagai pejabat negara yang diberi wewenang untuk itu, diucapkan dipersidangan dan bertujuan untuk mengakhiri atau menyelesaikan suatu perkara atau sengketa antara para pihak". ${ }^{15}$

Berdasarkan beberapa pengertian putusan tersebut di atas, maka dapat dikatakan bahwa putusan merupakan keputusan hakim untuk mengakhiri suatu perkata tertentu di antara para pihak. Sehingga ketika suatu putusan telah mempunyai kekuatan hukum tetap (in kracht van gewijsde), maka secara hukum putusan tersebut sudah berkekuatan hukum mengikat dan harus segera dilaksanakan, dengan tidak lagi menunggu keputusan dari lembaga negara lainnya. Karena kekuasaan peradilan didasarkan pada asas bebas dan mandiri, artinya segala proses hukum yang menjadi kewenangan peradilan tidak boleh ada campur tangan dari kekuasaan negara lainnya.

Teori hukum murni (teori Reine Rechtslehre atau The pure theory of law) yang terkenal dari Hans Kelsen, dapat dipakai untuk menentukan kedudukan putusan peradilan dalam sistem tata hukum sebagai sistem norma yang bertingkat. Putusan peradilan termasuk norma khusus yang mengatur suatu kasus tertentu. Tetapi lebih lanjut, Hans Kelsen menjelaskan bahwa:

\footnotetext{
${ }^{15}$ Irfan Fachruddin, Pengawasan Peradilan Administrasi terhadap Tindakan Pemerintah, Bandung: PT. Alumni, 2004, hlm. 227 - 228.
} 
Putusan pengadilan dapat juga melahirkan suatu norma umum. Putusan pengadilan bisa memiliki kekuatan mengikat bukan hanya bagi kasus tertentu yang ditangani saja melainkan juga bagi kasus-kasus serupa yang mungkin harus diputus oleh pengadilan. Suatu putusan pengadilan bisa memiliki karakter sebagai yurisprudensi, yaitu putusan yang mengikat bagi putusan mendatang dari semua kasus yang sama. ${ }^{16}$

Putusan pengadilan yang dimaksud di atas adalah putusan akhir (eind vonnis). Putusan akhir itu adalah putusan yang mengakhiri suatu sengketa perkara dalam suatu tingkatan peradilan tertentu. Di dalam beberapa literatur, terkenal tiga macam putusan akhir. Pertama, putusan declaratoir yaitu putusan yang isinya bersifat menerangkan atau menyatakan apa yang sah, dan putusan yang menolak permohonan. Menyatakan keadaan hukum tertentu yang dituntut oleh pemohon. Namun, di dalam peradilan administrasi tidak diperlukan pernyataan sah suatu keputusan dalam hal permohonan ditolak. Hal ini didasarkan adanya asas het vermoeden van rechtmatigheid atau presumtio justea couse, yaitu asas yang menyatakan demi kepastian hukum setiap keputusan administrasi dianggap benar menurut hukum. Kedua, putusan constitutive yaitu putusan yang meniadakan atau menciptakan suatu keadan hukum baru, yang pada umumnya tidak memerlukan pelaksanaan, karena tidak ada penetapan hak atas suatu prestasi. Ketiga, putusan comdemnatoir yaitu putusan yang bersifat menghukum pihak yang dikalahkan untuk memenuhi prestasi. $^{17}$

Di dalam Hukum acara MK dikenal dua asas putusan MK, yaitu Asas putusan yang bersifat final dan Asas putusan yang memiliki kekuatan hukum mengikat (erga omnes). MK merupakan pengadilan tingkat pertama dan terkahir, sehingga putusan yang dikeluarkan tersebut bersifat final, artinya putusan MK langsung memperoleh kekuatan hukum tetap sejak diucapkan dan tidak ada upaya hukum lagi yang dapat ditempuh. ${ }^{18}$ Sedangkan pengertian putusan MK mempunyai kekuatan hukum mengikat (erga omnes) adalah

\footnotetext{
${ }^{16}$ Ibid., hlm. $229-233$.

${ }^{17}$ Ibid., hlm. $237-238$.

${ }^{18}$ Pasal 24C ayat (1) Amandemen ketiga UUD NRI 1945 jo. Pasal 10 ayat (1) beserta penjelasannya dan Pasal 47 UU MK.
} 
putusan yang akibat hukumnya berlaku bagi semua perkara yang mengandung persamaan yang mungkin terjadi pada masa yang akan datang. Jadi, sekali peraturan perundang-undangan dinyatakan tidak sah, maka menjadi batal karena tidak sah untuk semua orang. Karena putusan MK bersifat erga omnes, maka mengikat secara obligatoir bagi seluruh organ negara, baik tingkat pusat, daerah, dan badan peradilan, serta semua otoritas lainnya. ${ }^{19}$

Menurut Sri Soemantri, putusan yang bersifat final harus juga bersifat mengikat dan tidak bisa dianulir oleh lembaga apapun. Dalam bahasa Inggris, pengertian yuridis final dan mengikat itu selalu bersatu, yaitu final and binding. Dengan demikian jika bersifat final harus diikuti dengan mengikat sehingga sah memiliki kepastian hukum. Kata final itu implisit telah mengikat dan tidak bisa dianulir sehinga tidak perlu ditambahi dengan kata mengikat. Menurut Indroharto, kata final merupakan akibat hukum yang ditimbulkan serta dimaksudkan dengan mengeluarkan penetapan tertulis itu harus benarbenar sudah merupakan akibat hukum yang definitif. ${ }^{20}$

Terdapat beberapa teori yang menjelaskan dasar tentang kekuatan mengikat dari pada suatu putusan, yaitu: ${ }^{21}$

a. Teori Hukum Materiil

Teori ini mengajarkan bahwa kekuatan mengikat putusan (gezag van gewijsde) mempunyai sifat hukum materiil, karena mengadakan perubahan terhadap wewenang dan kewajiban keperdataan, menetapkan, menghapuskan atau mengubah. Putusan ini dapat menimbulkan atau meniadakan hubungan hukum, sehingga putusan ini dapat dikatakan sumber hukum materiil.

b. Teori Hukum Acara

Teori ini mengajarkan bahwa putusan bukanlah sumber hukum materiil, tetapi sebagai sumber hukum dari wewenang prosesual. Siapa yang diakui sebagai pemilik, maka dengan sarana prosesual dapat bertindak sebagai pemilik terhadap lawannya.

\footnotetext{
${ }^{19}$ Abdul Rasyid Thalib, Op. cit., hlm. 55.

${ }^{20}$ Ibid., hlm. 491.

${ }^{21}$ Irfan Fachruddin, Op. cit., hlm. 245 - 246.
} 


\section{c. Teori Hukum Pembuktian}

Teori ini mengajarkan bahwa putusan merupakan bukti tentang apa yang ditetapkan di dalamnya, sehingga mempunyai kekuatan ukum mengikat.

d. Teori Daya Ikat

Teori ini mengajarkan bahwa terikatnya para pihak kepada putusan dapat mempunyai arti positif dan dapat pula mempunyai arti negatif. Dalam arti positif, yaitu apa yang telah diputus oleh hakim harus dianggap benar (res judicata pro veritate habetur) dan pembuktian lawan tidak dimungkinkan. Dalam arti negatif, yaitu hakim tidak boleh memutus perkara yang pernah diputus sebelumnya antara pihak yang sama serta mengenai pokok perkara yang sama.

e. Teori Kekuatan Hukum yang Pasti

Teori ini mengajarkan bahwa bahwa suatu putusan memperoleh kekuatan hukum yang pasti atau tetap (in kracht van gewijsde) apabila tidak ada lagi upaya hukum biasa yang tersedia. Dengan memperoleh kekuatan hukum yang tetap, suatu putusan tidak dapat diubah lagi sekalipun oleh pengadilan yang lebih tinggi, kecuali melalui upaya hukum luar biasa.

Dari kelima teori tersebut di atas, hanya teori yang kelima yang banyak dipergunakan dan menjadi dasar mengikatnya sebuah putusan. Jadi, suatu putusan sudah dapat dikatakan berkekuatan hukum mengikat jika sudah dinyatakan mempunyai kekuatan hukum tetap (in kracht van gewijsde).

Sesuai Pasal 24C ayat (1) dan ayat (2) Amandemen ketiga UUD NRI 1945, bahwa MK hanya memberikan putusan terhadap 5 (lima) perkara, yaitu :

a. pengujian undang-undang terhadap UUD NRI 1945;

b. memutus sengketa kewenangan lembaga negara yang kewenangannya diberikan oleh UUD NRI 1945;

c. memutus pembubaran partai politik;

d. memutus perselisihan tentang hasil pemilihan umum; dan

e. memutus pendapat DPR mengenai dugaan pelanggaran oleh Presiden dan/atau Wakil Presiden. 
Dari kelima macam putusan ini, terdapat perbedaan bentuk pelaksanaan putusan MK dalam hal permohonan dikabulkan, di antaranya:

a. Putusan dalam perkara pengujian undang-undang

Dalam hal permohonan dikabulkan, dimana putusan MK menyatakan bahwa materi muatan ayat, Pasal, dan/atau bagian undang-undang bertentangan dengan UUD NRI 1945, maka materi muatan ayat, Pasal, dan/atau bagian undang-undang tersebut dinyatakan tidak mempunyai kekuatan hukum mengikat. Sedangkan apabila putusan MK menyatakan bahwa pembentukan undang-undang tidak memenuhi ketentuan pembentukan undang-undang berdasarkan UUD NRI 1945, maka undangundang tersebut dinyatakan tidak mempunyai kekuatan hukum mengikat. Putusan MK ini wajib dimuat dalam Berita Negara dalam jangka waktu paling lambat 30 (tiga puluh) hari kerja sejak putusan diucapkan. ${ }^{22}$

b. Putusan dalam sengketa kewenangan lembaga negara

Dalam hal permohonan dikabulkan, putusan MK yang menyatakan bahwa termohon tidak mempunyai kewenangan untuk melaksanakan kewenangan yang dipersengketan, termohon wajib melaksanakan putusan tersebut dalam jangka waktu paling lama 7 (tujuh) hari kerja sejak putusan diterima oleh termohon. Jika putusan tersbut tidak dilaksanakan oleh termohon dalam jangka waktu 7 (tujuh) hari tersebut, maka pelaksanaan kewenangan termohon batal demi hukum. ${ }^{23}$

c. Putusan tentang pembubaran partai politik

Dalam hal permohonan dikabulkan, maka pelaksanan putusan pembubaran partai politik dilakukan dengan membatalkan pendaftaran pada Pemerintah. Putusan MK ini diumumkan oleh Pemerintah dalam Berita Negara dalam waktu paling lambat 14 (empat belas) hari sejak putusan diterima. ${ }^{24}$

d. Putusan tentang hasil pemilu

Dalam hal permohonan dikabulkan mengenai sengketa hasil pemilihan umum (Pemilu), maka MK menyatakan membatalkan hasil perhitungan

\footnotetext{
22 Pasal 57 ayat (1), ayat (2), dan ayat (3) UU MK.

${ }^{23}$ Pasal 66 ayat (1) dan ayat (2) UU MK.

${ }^{24}$ Pasal 73 ayat (1) dan ayat (2) UU MK.
} 
suara yang diumumkan oleh Komisi Pemilihan Umum (KPU) dan menetapkan hasil hasil perhitungan suara yang benar. ${ }^{25}$

e. "Putusan" mengenai dugaan pelanggaran oleh Presiden dan/atau Wakil Presiden

Apabila MK memutuskan bahwa Presiden dan/atau Wakil Presiden terbukti melakukan pelanggaran hukum berupa pengkhianatan terhadap negara, korupsi, penyuapan, tindak pidana berat lainnya, atau perbuatan tercela dan/atau terbukti tidak lagi memenuhi syarat sebagai Presiden dan/atau Wakil Presiden, maka amar "putusan" MK menyatakan "membenarkan pendapat DPR". ${ }^{26}$

Dari kelima bentuk pelaksanaan putusan MK tersebut, hanya empat yang berkekuatan hukum mengikat dan secara otomatis langsung dapat dilaksanakan sejak putusan MK telah dinyatakan in kracht van gewijsde tanpa menunggu lagi keputusan dari lembaga negara lainnya, yaitu putusan dalam perkara pengujian undang-undang, putusan dalam sengketa kewenangan lembaga negara yang kewenangannya diberikan oleh UUD NRI 1945, putusan tentang pembubaran partai politik, dan putusan tentang sengketa hasil pemilu. Sedangkan "putusan" MK tentang adanya dugaan pelanggaran oleh Presiden dan/atau oleh Wakil Presiden adalah tidak berkekuatan hukum mengikat, sehingga "putusan" MK ini masih belum bisa dilaksanakan.

Berdasarkan Pasal 7B ayat (1) Amandemen ketiga UUD NRI 1945, bahwa "putusan" MK tersebut masih harus disampaikan kepada DPR. Kemudian DPR mengajukan kepada MPR tentang usulan pemberhentian (impeachment) Presiden dan/atau Wakil Presiden. Karena memang secara kontitusional, lembaga negara yang berwenang untuk memberhentikan Presiden dan/atau Wakil Presiden adalah MPR. ${ }^{27}$ Jadi, karena MPR yang berwenang memberhentikan Presiden dan/atau Wakil Presiden, berarti "putusan" MK tersebut dapat saja tidak dilaksanakan oleh MPR.

\footnotetext{
25 Pasal 77 ayat (3) UU MK.

${ }^{26}$ Pasal 83 ayat (2) UU MK.

${ }^{27}$ Pasal 3 ayat (3) Amandemen ketiga UUD NRI 1945.
} 
Dengan demikian, maka dapat dikatakan bahwa "putusan" MK terhadap pendapat DPR mengenai dugaan adanya pelanggaran yang dilakukan oleh Presiden dan/atau Wakil Presiden tersebut tidak bersifat final, karena proses pemberhentian (impeachment) terhadap Presiden dan/atau Wakil Presiden tidak berhenti setelah adanya "putusan" MK, tetapi masih harus melalui sidang paripurna di lembaga DPR dan kemudian diteruskan ke lembaga MPR. Jadi, berhenti tidaknya Presiden dan/atau Wakil Presiden tersebut tergantung pada hasil keputusan politik di dalam rapat paripurna MPR sebagai lembaga yang berwenang melakukan impeachment terhadap Presiden dan/atau Wakil Presiden.

Di samping itu, putusan MK juga tidak mempunyai kekuatan hukum mengikat terhadap DPR dan MPR, karena MK bukanlah lembaga negara yang berwenang memberhentikan Presiden dan/atau Wakil Presiden, sehingga "putusan" MK tersebut hanyalah sebatas menjadi pertimbangan hukum bagi DPR dan MPR.

Ketentuan ini juga diperkuat dengan rumusan Pasal 24C ayat ayat (1) dan ayat (2) amandmen ketiga UUD NRI 1945, yaitu :

(1) Mahkamah Konstitusi berwenang mengadili pada tingkat pertama dan terkhir yang putusannya bersifat final untuk menguji undang-undang terhadap Undang-Undang dasar, memutus sengketa kewenangan lembaga Negara yng kewenangannya diberikan oleh Undang-Undang Dasar, memutus pembubaran partai politik, dan memutus perselisihan tentang hasil pemilihan umum.

(2) Mahkamah Konstitusi wajib memberikan putusan atas pendapat Dewan Perwakilan Rakyat mengenai dugaan pelanggaran oleh Presiden dan/atau Wakil Presiden menurut Undang-Undang Dasar.

Berdasarkan kedua rumusan ayat tersebut di atas, MK memutus pada tingkat pertama dan terkahir serta putusannya bersifat final hanya terhadap perkara pengujian undang-undang terhadap UUD NRI 1945, sengketa kewenangan lembaga negara yang kewenangannya diberikan oleh UUD NRI 1945, pembubaran partai politik, dan perselisihan tentang hasil pemilu. Sedangkan "putusan" MK terhadap pendapat DPR mengenai dugaan 
pelanggaran oleh Presiden dan/atau Wakil Presiden, "putusan” MK ini tidak bersifat final dan tidak mengikat.

MK memutus pada tingkat pertama dan terakhir yang putusannya bersifat final hanya diatur di dalam Pasal 24C ayat (1) Amandemen ketiga UUD NRI 1945, sedangkan ketentuan tentang kewajiban MK untuk memberikan "putusan" atas pendapat DPR mengenai dugaan adanya pelanggaran oleh Presiden dan Wakil Presiden, diatur secara terpisah dari Pasal 24C ayat (1), yaitu ditentukan di dalam Pasal 24C ayat (2) Amandemen ketiga UUD NRI 1945. Di dalam Pasal 24C ayat (2) Amandemen ketiga UUD NRI 1945 ini tidak ditentukan bahwa "MK merupakan tingkat pertama dan terkahir yang putusannya bersifat final”.

Pengaturan yang terpisah antara kewenangan dan kewajiban MK ini juga diatur di dalam Pasal 10 ayat (1) dan ayat (2) UU MK, yaitu :

(1) Mahkamah Konstitusi berwenang mengadili pada tingkat pertama dan terakhir yang putusannya bersifat final untuk :

a. menguji undang-undang terhadap Undang-Undang Dasar Negara Republik Indonesia Tahun 1945;

b. memutus sengketa kewenangan lembaga negara yang kewenangannya diberikan oleh Undang-Undang Dasar Negara Republik Indonesia Tahun 1945;

c. memutus pembubaran partai politik; dan

d. memutus perselisihan tentang hasil pemilihan umum.

(2) Mahkamah Konstitusi wajib memberikan putusan atas pendapat DPR bahwa Presiden dan/atau Wakil Presiden diduga telah melakukan pelanggaran hukum berupa pengkhianatan terhadap negara, korupsi, penyuapan, tindak pidana berat lainnya, atau perbuatan tercela, dan/atau tidak lagi memenuhi syarat sebagai Presiden dan/atau Wakil Presidensebagaimana dimaksud dalam Undang-Undang Dasar Negara Republik Indonesia Tahun 1945; 
Di dalam lampiran UU Nomor 12 Tahun 2011 tentang Pembentukan Peraturan Perundang-undangan ditentukan bahwa dalam satu ayat itu hanya memuat satu norma yang dirumuskan dalam satu kalimat utuh. Jadi, dengan dipisahkannya antara ayat yang menjadi kewenangan MK dengan ayat yang menjadi kewajiban MK dapat diartikan bahwa keduanya mempunyai norma yang berbeda, sehingga putusan MK yang bersifat final dan terakhir hanya pada perkara pengujian undang-undang terhadap UUD NRI 1945, memutus sengketa kewenangan lembaga negara yang lewenangannya diberikan oleh Undang-Undang Dasar Negara Republik Indonesia Tahun 1945; memutus pembubaran partai politik; dan memutus perselisihan tentang hasil pemilihan umum. Sedangkan "putusan" MK atas pendapat DPR mengenai dugaan pelanggaran oleh Presiden dan/atau Wakil Presiden tidaklah bersifat final.

Dengan beberapa alasan tersebut di atas, maka sebenarnya "putusan" MK atas pendapat DPR tentang dugaan adanya pelanggaran oleh Presiden dan Wakil Presiden sebagaimana yang diatur di dalam ayat (2) Pasal 24C Amandemen ketiga UUD NRI 1945 jo. Pasal 10 ayat (2) UU MK tersebut tidak bersifat final dan tidak mempunyai kekuatan hukum mengikat terhadap DPR maupun MPR.

Seharusnya putusan MK atas pendapat DPR itu harus disamakan dengan perkara lain yang menjadi kewenangan MK, yakni sama-sama dinyatakan berkuatan hukum mengikat, artinya putusan MK itu mengikat dan harus dilaksanakan oleh DPR maupun MPR. MK sebagai lembaga yudisial sebenarnya hanya memberikan legalitas atas pendapat DPR apakah Presiden dan/atau Wakil Presiden terbukti secara hukum atau tidak melakukan pelanggaran maupun tidak lagi memenuhi syarat sebagai Presiden dan/atau Wakil Presiden.

Apabila MK telah menyatakan bahwa Presiden dan/atau Wakil Presiden terbukti melakukan pelanggaran maupun tidak lagi memenuhi syarat sebagai Presiden dan/atau Wakil Presiden, maka berarti Presiden dan/atau Wakil Presiden telah sah untuk dinyatakan telah melakukan pelanggaran 
konstitusional atau tidak lagi memenuhi syarat konstitusional sebagai Presiden dan/atau Wakil Presiden.

Jadi, keputusan MPR tentang pemberhentian Presiden dan/atau Wakil Presiden sebenarnya bukan untuk melaksanakan putusan MK tetapi sebagai pelaksanaan dari ketentuan konstitusional karena terpenuhi dan terbuktinya alasan-alasan pemberhentian Presiden dan/atau Wakil Presiden sebagaimana diatur pada Pasal 7A Amandemen ketiga UUD NRI 1945.

Sejak UUD 1945 dilakukan Amandemen ketiga, maka kedaulatan tidak lagi berada pada MPR, akan tetapi berada pada tangan rakyat dan dilaksanakan menurut UUD NRI 1945. Hal ini berarti Indonesia sekarang tidak lagi menerapkan kedaulatan MPR (kedaulatan politik), akan tetapi telah menerapkan kedaulatan konstitusi (kedaulatan hukum). Ini artinya semua persoalan kenegaraan harus melalui dan diselesaikan secara konstitusional atau secara hukum.

Jika impeachment Presiden dan/atau Wakil Presiden didasarkan secara penuh kepada keputusan politik MPR, ini berarti Indonesia masih menerapkan kedaulatan politik (kembali sebagaimana UUD 1945 sebelum diamandemen), meskipun Presiden dan/atau Wakil Presiden telah terbukti secara sah dan meyakinkan melanggar ketentuan konstitusional. Di samping itu juga, pelaksanaan ketentuan Pasal 1 ayat (3) Amandemen ketiga UUD NRI 1945 yang menyatakan bahwa "Negara Indonesia adalah negara hukum" menjadi semu dan tidak jelas, karena dalam praktiknya bukan hukum yang berdaulat tetapi politik.

\section{DAMPAK KONSTITUSIONAL PUTUSAN MK TERHADAP KEPUTUSAN DPR MAUPUN MPR DALAM PROSES IMPEACHMENT PRESIDEN DAN/ATAU WAKIL PRESIDEN}

\section{Alasan Impeachment Presiden dan/atau Wakil Presiden}

Beberapa alasan yang dapat digunakan untuk melakukan impeachment terhadap Presiden dan/atau Wakil Presiden adalah sebagaimana diatur dalam Pasal 7A Amandemen ketiga UUD NRI 1945, yaitu: 
Presiden dan/atau Wakil Presiden dapat diberhentikan dalam masa jabatannya oleh Majelis Permusyawaratan Rakyat atas usul Dewan Perwakilan Rakyat, baik apabila terbukti telah melakukan pelanggaran hukum berupa pengkhianatan terhadap negara, korupsi, penyuapan, tindak pidana berat lainnya, atau perbuatan tercela maupun apabila terbukti tidak lagi memenuhi syarat sebagai Presiden dan/atau Wakil Presiden.

Lebih lanjut alasan tentang impeachment terhadap Presiden dan/atau Wakil Presiden ini di jelaskan di dalam Pasal 10 ayat (2) UU MK, yaitu:

Mahkamah Konstitusi wajib memberikan putusan atas pendapat DPR bahwa Presiden dan/atau Wakil Presiden diduga telah melakukan pelanggaran hukum berupa pengkhianatan terhadap negara, korupsi, penyuapan, tindak pidana berat lainnya, atau perbuatan tercela, dan/atau tidak lagi memenuhi syarat sebagai Presiden dan/atau Wakil Presiden sebagaimana dimaksud dalam Undang-Undang Dasar Negara Republik Indonesia Tahun 1945;

Berdasarkan pada Pasal 7A Amandemen ketiga UUD NRI 1945 Pasal 10 ayat (2) UU MK bahwa terdapat dua alasan untuk memberhentikan atau meng-impeach Presiden dan/atau Wakil Presiden, yaitu pertama karena terbukti secara hukum Presiden dan/atau Wakil Presiden melakukan pelanggaran. Kedua, karena Presiden dan/atau Wakil Presiden tidak lagi memenuhi syarat lagi sebagai Presiden dan/atau Wakil Presiden.

Adapun yang dimaksud dengan "pelanggaran" adalah sebagaimana disebutkan di dalam Pasal 7A itu sendiri, yaitu terbatas pada 5 (enam) perkara, yaitu :

a. pengkhianatan terhadap negara

b. korupsi

c. penyuapan

d. tindak pidana berat lainnya

e. perbuatan tercela

Batasan mengenai pelanggaran sebagaimana disebutkan dalam Pasal 7A Amandemen ketiga UUD NRI 1945 Pasal 10 ayat (2) UU MK adalah dijelakan dalam ketentuan Pasal 10 ayat (3) UU MK, yaitu: 
2. pengkhianatan terhadap Negara adalah tindak pidana terhadap keamanan negara sebagaimana diatur di dalam undang-undang.

3. Korupsi dan penyuapan adalah tindak pidana korupsi atau penyuapan sebagaimana diatur dalam undang-undang.

4. Tindak pidana berat lainnya adalah tindak pidana diancamdengan pidana penjara 5 (lima) tahun atau lebih.

5. Perbuatan tercela adalah perbuatan yang dapat merendahkan martabat Presiden dan/atau Wakil Presiden.

6. Tidak lagi memenuhi syarat sebagai Presiden dan/atau Wakil Presiden adalah syarat sebagaimana ditentukan dalam Pasal 6 Undang-Undang Dasar Negara Republik Indonesia Tahun 1945.

Alasan kedua untuk dapat memberhentikan Presiden dan/atau Wakil Presiden adalah jika Presiden dan/atau Wakil Presiden tidak lagi memenuhi syarat sebagai Presiden dan/atau Wakil Presiden.

Adapun beberapa syarat sebagai Presiden dan/atau Wakil Presiden adalah sebagaimana disebutkan di dalam Pasal 6 ayat (1) Amandemen ketiga UUD NRI 1945, yaitu:

Calon Presiden dan Wakil Presiden harus seorang warga negara Indonesia sejak kelahirannya dan tidak pernah menerima kewarganegaraan lain karena kehendaknya sendiri, tidak pernah mengkhianati negara, serta mampu secara rohani dan jasmani untuk melaksanakan tugas dan kewajiban sebagai Presiden dan Wakil Presiden.

\section{Proses Impeachment Presiden dan/atau Wakil Presiden}

Di dalam sistem pemerintahan Indonesia, di samping Presiden sebagai Kepala Negara juga sebagai Kepala Pemerintahan yang dibantu oleh seorang Wakil Presiden yang dipilih secara langsung dalam satu pasangan. Dengan demikian, Proses tentang impeachment Presiden dan/atau Wakil Presiden ini diatur di dalam konstitusi negara. Pengaturan tentang Proses impeachment 
Presiden dan/atau Wakil Presiden di Indoenesia ini sebagaimana ditentukan di dalam Pasal 7B ayat (1) Amandemen ketiga UUD NRI 1945, yaitu:

Usul Pemberhentian Presiden dan/atau Wakil Presiden dapat diajukan oleh Dewan Perwakilan Rakyat kepada Majelis Perwakilan Rakyat hanya dengan terlebih dahulu mengajukan permintan kepada Mahkamah Konstitusi untuk memeriksa, mengadili, dan memutus pendapat Dewan Perwakilan Rakyat bahwa Presiden dan/atau Wakil Presiden telah melakukan pelanggaran hukum berupa pengkhianatan terhadap negara, korupsi, penyuapan, tindak pidana berat lainnya, atau perbuatan tercela; dan/atau pendapat bahwa Presiden dan/atau Wakil Presiden tidak lagi memenuhi syarat sebagai Presiden dan/atau Wakil Presiden.

Berdasarkan ketentuan Pasal 7B ayat (1) Amandemen ketiga UUD NRI 1945 ini, maka proses impeachment terhadap Presiden dan/atau Wakil Presiden tersebut adalah:

a. Adanya pendapat DPR bahwa Presiden dan/atau Wakil Presiden telah melakukan pelanggaran hukum

b. DPR mengajukan permintaan kepada MK untuk memberikan "putusan"

c. MK menyampaikan "putusan" kepada DPR

d. DPR mengajukan usul Impeachment Presiden dan/atau Wakil Presiden kepada MPR

e. MPR mengadakan rapat paripurna untuk memutuskan usul DPR

Dari beberapa Proses impeachment terhadap Presiden dan/atau Wakil presiden tersebut di atas dapat dijelaskan sebagaimana di bawah ini :

1) Pendapat DPR Bahwa Presiden dan/atau Wakil Presiden telah Melakukan Pelanggaran Hukum

Pendapat ini merupakan hak DPR dalam menyatakan pendapat sebagai tindak lanjut dari dugaan DPR mengenai pelanggaran hukum oleh Presiden dan/atau Wakil Presiden. Hal ini sebagaimana disebutkan di dalam Pasal 77 ayat (4) UU Parlemen, yaitu:

Hak menyatakan pendapat sebagaimana dimaksud pada ayat (1) huruf c adalah hak DPR untuk menyatakan pendapat atas :

a. kebijakan pemerintah atau mengenai kejadian luar biasa yang terjadi di tanah air atau di dunia internasional; 
b. tindak lanjut pelaksanaan hak interpelasi sebagaimana dimaksud pada ayat (2) dan hak angket sebagaimana dimaksud pada ayat (3); atau

c. dugaan bahwa Presiden dan/atau Wakil Presiden melakukan pelanggaran hukum baik berupa pengkhianatan terhadap negara, korupsi, penyuapan, tindak pidana berat lainnya, maupun perbuatan tercela, dan/atau Presiden dan/atau Wakil Presiden tidak lagi memenuhi syarat sebagai Presiden dan/atau Wakil Presiden.

Berdasarkan Pasal 77 ayat (4) huruf c UU Parlemen ini, hak menyatakan pendapat oleh DPR untuk mengajukan usul impeachment Presiden dan/atau Wakil Presiden kepada MPR adalah sebagai wujud pelaksanaan dari adanya dugaan DPR bahwa Presiden dan/atau Wakil Presiden telah melakukan pelanggaran hukum berupa pengkhianatan terhadap negara, korupsi, penyuapan, tindak pidana berat lainnya atau perbuatan tercela maupun tidak lagi memenuhi syarat sebagai Presiden dan/atau Wakil Presiden. Ketentuan ini sesuai dengan Pasal 24C ayat (2) Amandemen ketiga UUD NRI 1945, yaitu: "Mahkamah Konstitusi wajib memberikan putusan atas pendapat Dewan Perwakilan Rakyat mengenai dugaan pelanggaran oleh Presiden dan/atau Wakil Presiden menurut Undang-Undang Dasar”.

Pendapat DPR mengenai dugaan adanya pelanggaran hukum oleh Presiden dan/atau Wakil Presiden ini baru dapat dijadikan dasar untuk mengajukan usul impeachment ketika sudah mendapatkan dukungan sekurang-kurangnya 2/3 dari jumlah anggota DPR yang hadir yang dihadiri oleh sekurang-kurangnya 2/3 dari jumlah anggota DPR. Jika keberlanjutan dugaan DPR ini harus didasarkan pada banyak tidaknya dukungan politik dari anggota DPR, maka berarti proses usul impechment terhadap Presiden dan/atau Wakil Presiden di dalam rapat paripurna DPR tersebut bukanlah merupakan proses hukum, tetapi an sich proses politik.

Berdasarkan ketentuan ini, maka dapat dikatakan bahwa usul pemberhentian Presiden dan/atau Wakil Presiden oleh DPR ini sangat rentan dengan muatan politis, karena DPR dapat saja mengajukan usul 
impeachment terhadap Presiden dan/atau Wakil Presiden hanya atas dasar dugaan semata. Rumusan yang seperti ini sangat berpengaruh terhadap objektifitas penggunaan hak menyatakan pendapat DPR.

1) DPR Mengajukan Permintaan Kepada MK untuk Memberikan "Putusan" Setelah dugaan DPR mengenai adanya pelanggaran hukum yang dilakukan oleh Presiden dan/atau Wakil Presiden ini telah mendapatkan dukungan sekurang-kurangnya 2/3 dari jumlah anggota DPR yang hadir dalam rapat paripurna yang dihadiri oleh sekurang-kurangnya $2 / 3$ dari jumlah anggota DPR, maka dugaan tersebut dapat diajukan permintaan kepada MK oleh DPR untuk diperiksa, diadili dan diberikan "putusan" berdasarkan buktibukti yang terungkap di persidangan. Hal ini sebagaimana diatur di dalam Pasal 7B ayat (3) Amandemen ketiga UUD NRI 1945, yaitu: "Pengajuan permintaan Dewan Perwakilan Rakyat kepada Mahkamah Konstitusi hanya dapat dilakukan dengan dukungan sekurang-kurang 2/3 dari jumlah anggota Dewan Perwakilan Rakyat yang hadir dalam sidang paripurna yang dihadiri oleh sekurang-kurangnya $2 / 3$ dari jumlah anggota Dewan Perwakilan Rakyat."

2) MK Menyampaikan Putusan Kepada DPR

Berdasarkan pengajuan permintaan DPR tersebut, maka MK wajib sudah memberikan "putusan" atas pendapat DPR paling lama 90 (sembilan puluh) hari sejak MK menerima pengajuan permintaan DPR tersebut. Hal ini sebagaimana diatur di dalam Pasal 7B ayat (4) Amandemen ketiga UUD NRI 1945, yaitu: "Mahkamah Konstiusi wajib memeriksa, mengadili, dan memutus dengan seadil-adilnya terhadap pendapat Dewan Perwakilan Rakyat tersebut paling lama sembilan puluh setelah permintaan Dewan Perwakilan Rakyat itu diterima oleh Mahkamah Konstitusi”.

Meskipun antara Pasal 7A Amandemen ketiga UUD NRI 1945 menggunakan redaksi "terbukti" yang berbeda dengan redaksi "dugaan pelanggaran" di dalam Pasal 24C ayat (2) Amandemen ketiga UUD NRI 1945, tetapi di dalam amar "putusan" MK tetap sama menyatakan "membenarkan pandapat DPR". Jika pendapat DPR tersebut tidak terbukti 
di persidangan MK, maka amar "putusan" MK menyatakan "permohonan ditolak" [(Pasal 83 ayat (2) dan ayat (3) UU MK)].

Namun demikian, "putusan" MK tersebut bukanlah bersifat vonis, karena "putusan" MK tersebut tidak langsung berkekuatan hukum mengikat (orge omnes) sejak "putusan" MK tersebut sudah selesai dibacakan dalam sidang yang terbuka untuk umum dan telah berkekuatan hukum tetap (in khrach van gewisde). "Putusan" MK tersebut masih harus disampaikan kepada DPR serta masih harus diputuskan di dalam rapat paripurna MPR ${ }^{28}$. Dengan demikian, "putusan" MK tersebut bukanlah putusan dalam arti vonis, tetapi hanya sebagai "pertimbangan hukum" bagi DPR maupun bagi MPR.

3) DPR Mengajukan Usul Impeachment Presiden dan/atau Wakil Presiden Kepada MPR

Setelah MK memberikan "putusan" bahwa Presiden dan/atau Wakil Presiden terbukti melakukan pelanggarana hukum dengan amar "putusan" menyatakan "membenarkan pendapat DPR", maka baru DPR dapat mengajukan usul pemberhentian Presiden dan/atau Wakil Presiden tersebut kepada MPR. Hal ini sesuai dengan Pasal 7B ayat (5) Amandemen ketiga UUD NRI 1945, yaitu:

Apabila Mahkamah Konstitusi memutuskan bahwa Presiden dan/atau Wakil Presiden terbukti melakukan pelanggaran hukum berupa pengkhianatan terhadap negara, korupsi, penyuapan, tindak pidana berat lainnya, atau perbuatan tercela; dan/atau terbukti bahwa Presiden dan/atau Wakil Presiden tidak lagi memenuhi syarat sebagai Presiden dan/atau Wakil Presiden, Dewan Perwakilan Rakyat menyelenggarakan sidang paripurna untuk meneruskan usul pemberhentian Presiden dan/atau Wakil Presiden kepada Majelis Permusyawaratan Rakyat.

Rumusan di dalam Pasal 7B ayat (5) Amandemen ketiga UUD NRI 1945 ini masih terdapat beberapa kelemahan, di antaranya:

a. tidak ditentukannya batasan waktu paling lama bagi DPR untuk mengajukan usul pemberhetian Presiden dan/atau Wakil Presiden kepada

${ }^{28}$ Pasal 7B ayat (5), ayat (6) dan ayat (7) Amandemen ketiga UUD NRI 1945. 
MPR setelah DPR menerima "putusan" MK yang menyatakan "membenarkan pendapat DPR" tersebut. DPR merupakan lembaga politik, dimana semua pertimbangannya hanya didasarkan pada dinamika politik di dalam DPR. Konsolidasi dan perubahan politik terjadi sangat cepat bahkan bisa setiap detik, sehingga sangat memungkinkan keputusan politik DPR saat akan mengajukan permintaan kepada MK berbeda dengan dinamika politik pasca lahirnya "putusan" MK yang menyatakan "membenarkan pendapat DPR".

b. Kelemahan ini ditambah juga dengan tidak adanya pengaturan secara jelas tentang quorum DPR sebagai syarat untuk dapat mengajukan usul pemberhetian Presiden dan/atau Wakil Presiden tersebut kepada MPR. Dengan demikian, proses impeachment Presiden dan/atau Wakil Presiden itu semakin tidak jelas legalitas politiknya dan sampai kapan selesainya. "Putusan" MK tersebut tidak serta merta langsung mewajibkan kepada DPR untuk segera mengajukan usul pemberhentian Presiden dan/atau Wakil Presiden kepada MPR, karena yang mempunyai hak untuk mengajukan usul pemberhentian kepada MPR itu adalah DPR.

c. Jika UUD NRI 1945 itu memang tidak menentukan batasan waktu paling lama dan batasan quorum, maka berarti usul pemberhentian Presiden dan/atau Wakil Presiden kepada MPR itu tergantung pada dinamika politik di dalam DPR, sehingga diteruskan atau tidak usul pemberhentian Presiden dan/atau Wakil Presiden kepada MPR itu juga tergantung dinamika dan kesepakatan politik di DPR. Karena memang lembaga yang punya hak untuk mengusulkan pemberhentian tersebut adalah DPR $^{29}$. Dengan demikian, apabila DPR tidak jadi meneruskan usul pemberhentian Presiden dan/atau Wakil Presiden kepada MPR tersebut, maka ini tidaklah melanggar konstitusi (konstitusional). Hal ini juga diperkuat dengan tidak jelasnya rumusan di dalam Pasal 7B ayat (5) Amandemen ketiga UUD NRI 1945 yang hanya menyatakan "Dewan Perwakilan Rakyat menyelenggarakan sidang paripurna”. Redaksi ini

${ }^{29}$ Pasal 7B ayat (1) Amandemen ketiag UUD NRI 1945. 
jelas-jelas tidak memberikan sebuah kewajiban kepada DPR untuk meneruskan usul pemberhentian Presiden dan/atau Wakil Presiden kepada MPR.

4) MPR Mengadakan Rapat Paripurna Untuk Memutuskan Usul DPR

Ketika MPR telah menerima usul pemberhetian Presiden dan/atau Wakil Presiden dari DPR, maka MPR wajib menyelenggarakan sidang untuk memutuskan usul DPR tersebut paling lambat 30 (tiga puluh) hari. Hal ini sebagaimana diatur di dalam Pasal 7B ayat (6) Amandemen ketiga UUD NRI 1945, yaitu: "Majelis Permusyawaratan Rakyat wajib menyelenggarakan sidang untuk memutuskan usul Dewan Perwakilan Rakyat tersebut paling lambat tiga puluh hari sejak Majelis Permusyawaratan Rakyat menerima usul tersebut”.

Pengambilan keputusan MPR mengenai diberhentikan atau tidaknya Presiden dan/atau Wakil Presiden harus diambil di dalam rapat paripurna MPR yang dihadiri oleh sekurang-kurangnya 3/4 (tiga perempat) dari jumlah anggota MPR dan disetujui oleh sekurang-kurangnya 2/3 (dua pertiga) dari jumlah anggota MPR yang hadir. Hal ini sebagaimana diatur di dalam Pasal 7B ayat (7) Amandemen ketiga UUD NRI 1945, yaitu:

Keputusan Majelis Permusyawaratan Rakyat atas usul pemberhetian Presiden dan/atau Wakil Presiden harus diambil dalam rapat paripurna Majelis Permusyawaratan Rakyat yang dihadiri oleh sekurangkurangnya 3/4 dari jumlah anggota dan disetujui oleh sekurangkurangnya 2/3 dari jumlah anggota yang hadir, setelah Presiden dan/atau Wakil Presiden diberi kesempatan menyampaikan penjelasan dalam rapat paripurna Majelis Permusyawaratan Rakyat.

Berdasarkan ketentuan Pasal ini, Presiden dan/atau Wakil Presiden diberi kesempatan terlebih dahulu untuk menyampaikan penjelasan mengenai kasus yang menjadi alasan impeachment sebelum MPR memberikan keputusan. Namun, apakah penjelasan Presiden dan/atau Wakil Presiden di hadapan sidang paripurna MPR tersebut dapat merubah keputusan MPR? Hal ini sebenarnya tergantung pada kekuatan dan kesepakatan politik di dalam MPR, karena yang mempunyai wewenang 
memberherikan Presiden dan/atau Wakil Presiden ditengah masa jabatannya ini adalah MPR. Penjelasan Presiden dan/atau Wakil Presiden tersebut hanyalah sebatas bahan pertimbangan MPR dalam memberikan keputusan politiknya.

Atas dasar bahwa lembaga yang berwenang untuk memberhentikan Presiden dan/atau Wakil Presiden dalam masa jabatannya ini adalah MPR sebagaimana ditentukan pada Pasal 3 ayat (3) Amandemen ketiga UUD NRI 1945, maka baik "putusan" MK maupun penjelasan Presiden dan/atau Wakil Presiden di hadapan sidang paripurna MPR tersebut hanyalah menjadi bahan "pertimbangan hukum" bagi MPR untuk memberikan keputusan.

Wewenang MPR untuk dapat memberhentikan Presiden dan/atau Wakil Presiden di tengah masa jabatannya ini didasarkan pada asas contrario actus, yaitu karena pengesahan pengangkatan Presiden dan/atau Wakil Presiden dilakukan oleh MPR sebagaimana ditentukan pada Pasal 9 ayat (1) Amandemen pertama UUD NRI 1945, maka pengesahan pemberhetian Presiden dan/atau Wakil Presiden juga dilakukan oleh MPR. ${ }^{30}$

Dengan demikian, ketika keputusan MPR tersebut berbeda dengan Putusan MK, maka keputusan MPR tersebut bukanlah merupakan tindakan yang melanggar konstitusi. Hal ini didasarkan pada ketentuan Pasal 3 ayat (3) Amandemen ketiga UUD NRI 1945 yang manyatakan bahwa MPR lah yang hanya mempunyai wewenang untuk memberhetikan Presiden dan/atau Wakil Presiden dalam masa jabatannya. Selain itu juga didasarkan pada asas contrario actus tersebut.

Berikut skema proses impeachment Presiden dan/atau Wakil Presiden sebagaimana pada penjelasan di atas, yaitu:

${ }^{30}$ Abdul Rasyid Thalib, Op. cit., hal. 478 


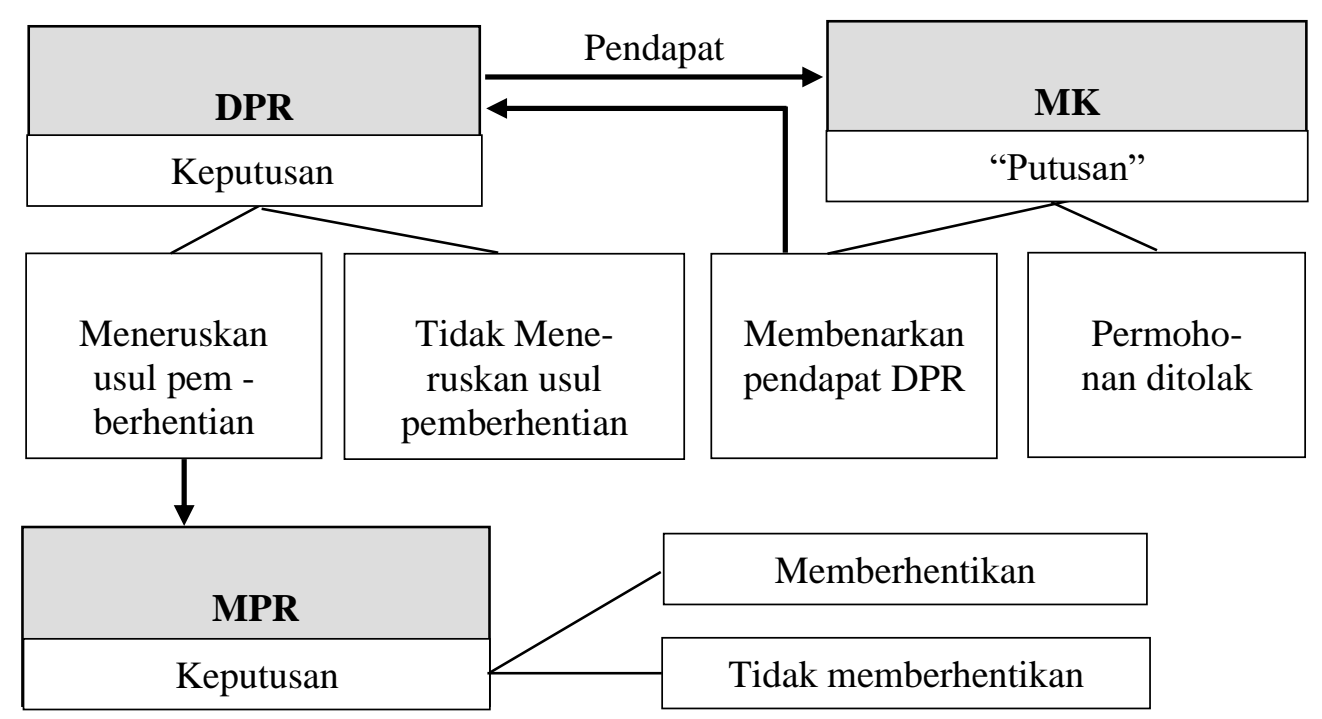

Berdasarkan proses impeachment terhadap Presiden dan/atau Wakil Presiden di atas, maka Proses impeachment di Indoensia sebagaimana diatur di dalam UUD NRI 1945 adalah melalui dua tahap, yaitu:

Pertama, pada tahap proses pemeriksaan hukum oleh MK tentang pendapat DPR mengenai dugaan pelanggaran hukum oleh Presiden dan/atau Wakil Presiden melalui special legal proceedings. Akan tetapi, putusan MK atas pendapat DPR ini masih belum bersifat final dan tidak mempunyai kekuatan hukum mengikat karena masih harus diteruskan lagi dan diputuskan di sidang paripurna MPR.

Kedua, tahap pengambilan keputusan pemberhentian Presiden dan/atau Wakil Presiden dilakukan melalui proses legislatif di dalam rapat paripurna MPR.

Dengan demikian, impeachment terhadap Presiden dan/atau Wakil Presiden baru dapat terjadi, jika didasarkan atas dua dasar hukum. Pertama, atas dasar putusan MK yang menyatakan bahwa Presiden dan/atau Wakil Presiden telah terbukti melakukan pelanggaran hukum setelah dibuktikan melalui special legal proceedings ${ }^{31}$. Adapun dasar kedua adalah keputusan MPR yang menyatakan bahwa Presiden dan/atau wakil Presiden diberhentikan dari jabatannya setelah dimintai keterangan di dalam rapat

${ }^{31}$ Pasal 7B ayat (5) Amandemen ketiga UUD NRI 1945. 
paripurna MPR yang dilakukan melalui cara legislatif (proses politik di MPR) $)^{32}$.

Jika ditafsirkan secara a contrario terhadap rumusan Pasal 7B ayat (5) Amendemen ketiga UUD NRI 19454 di atas, maka berarti DPR tidak boleh meneruskan usul pemberhentian Presiden dan/atau Wakil Presiden kepada MPR ketika MK memutuskan bahwa Presiden dan/atau Wakil Presiden tidak terbukti melakukan pelanggaran hukum atau pendapat DPR dinyatakan ditolak. Tetapi jika DPR tetap meneruskan usul pemberhentian Presiden dan/atau Wakil Presiden tersebut kepada MPR karena desakan politik di dalam DPR sangat kuat, maka tindakan DPR tersebut dapat dianggap sebagai tindakan yang inkonstitusional (melanggar konstitusi negara).

Meskipun aturan ini telah terumuskan di dalam Pasal Pasal 7B ayat (5) Amendemen ketiga UUD NRI 19454 ini, akan tetapi tidak menutup kemungkinan DPR akan tetap mengusulkan pemberhentian Presiden dan/atau Wakil Presiden kepada MPR meskipun MK telah memutuskan bahwa pendapat DPR dinyatakan ditolak karena Presiden dan/atau Wakil Presiden tidak terbukti melakukan pelanggaran hukum. Hal ini karena di dalam rumusan Pasal 7B ayat (6) Amandemen ketiga UUD NRI 1945 masih memberikan peluang untuk bisa terjadi, yaitu adanya rumusan bahwa MPR wajib memutuskan usul pemberhentian Presiden dan/atau Wakil Presiden yang diajukan oleh DPR. Jadi yang wajib diputuskan di dalam rapat paripurna MPR tersebut adalah tentang "usul DPR", bukan memberikan keputusan atas "putusan MK" atas pengajuan usul DPR.

Konsekuensi hukum dari rumusan 7B ayat (6) Amandemen ketiga UUD NRI 1945 tersebut adalah ketika DPR tetap mengajukan usul pemberhentian Presiden dan/atau Wakil Presiden kepada MPR, maka MPR tetap wajib menyelenggarakan rapat paripurna untuk memutuskan pendapat DPR tersebut meskipun tindakan DPR tersebut kontradiktif dengan "putusan" MK.

${ }^{32}$ Pasal 7B ayat (7) Amandemen ketiga UUD NRI 1945. 
Atas dasar inilah, maka yang dianggap inkonstitusional adalah tindakan DPR, sedangkan tindakan MPR tetap konstitusional. Hal ini didasarkan pada rumusan di dalam 7B ayat (5) dan ayat (6) Amandemen ketiga UUD NRI 1945. Meskipun demikian, Proses pemberhentian Presiden dan/atau Wakil Presiden tersebut tetap dianggap inkonstitusional, karena melanggar ketentuan Pasal 7B ayat (5) amandemen ketiga UUD NRI 1945.

\section{PENUTUP}

\section{Kesimpulan}

a. Bahwa "putusan" $\mathrm{MK}$ atas pendapat DPR mengenai dugaan pelanggaran hukum oleh Presiden dan/atau Wakil Presiden adalah tidak mempunyai kekuatan hukum mengikat terhadap DPR maupun MPR. Hal ini didasarkan pada alasan, pertama karena pemberhentian Presiden dan/atau Wakil Presiden ini masih harus diputuskan lagi melalui rapat paripurna MPR berdasarkan usul DPR setelah MK memutuskan bahwa Presiden dan/atau Wakil Presiden terbukti melakukan pelanggaran hukum (Pasal 7B ayat (7) dan ayat (5) Amandemen ketiga UUD NRI 1945). Kedua, karena usul pemberhentian Presiden dan/atau Wakil Presiden itu merupakan hak dari DPR, sehingga diteruskan atau tidak usul pemberhentian itu tergantung kepada keputusan DPR. Ketiga, kerena lembaga negara yag berwenang memberhentikan Presiden dan/atau Wakil Presiden dalam masa jabatannya adalah MPR, bukan MK (Pasal 3 ayat (3) Amandemen ketiga UUD NRI 1945), sehingga keputusan mengenai diberhentikan atau tidaknya Presiden dan/atau Wakil Presiden itu tergantung kepada keputusan MPR (Pasal 7B ayat (7) Amandemen ketiga UUD NRI 1945). Dengan demikian, "Putusan" MK atas pendapat DPR bukan bersifat vonis, tetapi hanyalah “pertimbangan hukum” bagi DPR maupun MPR.

b. Dengan demikian, "putusan" MK atas pendapat DPR mengenai dugaan adanya pelanggaran hukum oleh Presiden dan/atau Wakil Presiden tersebut tidaklah berimplikasi konstitusional terhadap keputusan DPR 
maupun MPR, kecuali jika DPR tetap mengajukan usul pemberhentian kepada MPR sedangkan MK telah memutuskan bahwa Presiden dan/atau Wakil Presiden tidak terbukti melakukan pelanggaran hukum, maka keputusan DPR tersebut dapat dianggap inkonstitusional (Pasal 7B ayat (5) Amandemen ketiga UUD NRI 1945), karena usul pemberhentian terhadap Presiden dan/atau Wakil Presiden oleh DPR harus atas adanya "putusan" MK yang menyatakan bahwa Presiden dan/atau Wakil Presiden terbukti telah melakukan pelanggaran hukum (Pasal 7B ayat (5) Amandemen ketiga UUD NRI 1945). Namun, jika DPR memutuskan untuk tidak meneruskan usul pemberhentian tersebut kepada MPR meskipun MK telah memutuskan bahwa Presiden dan/atau Wakil Presiden terbukti melakukan pelanggaran hukum, maka hal ini masih termasuk tindakan yang konstitusional, karena usul pemberhentian merupakan hak dari DPR (Pasal 7B ayat (1) Amandemen ketiga UUD NRI 1945). Selain itu, jika keputusan MPR ternyata berbeda dengan "putusan" MK, maka hal ini juga tetap termasuk tindakan yang konstitusional, karena pemberhentian Presiden dan/atau Wakil Presiden itu merupakan wewenang MPR (Pasal 3 ayat (3) Amandemen ketiga UUD NRI 1945).

\section{Saran}

a. Agar impeachment Presiden dan/atau Wakil Presiden ini an sich sebagai pelaksanaan dari kedaulatan hukum sebagaimana dikehendaki di dalam Pasal 1 ayat (2) Amandemen ketiga UUD NRI 1945, maka seharusnya putusan MK itu berkekuatan hukum mengikat terhadap DPR maupun MPR sejak putusan MK dinyatakan telah mempunyai kekuatan hukum tetap (in kracht van gewijsde), sehingga DPR dan MPR tersebut harus memberikan keputusan politik sesuai dengan pernyataan MK yang membenarkan pendapat DPR. Keputusan DPR maupun MPR tersebut hanyalah sebagai Proses politik saja. Hal ini untuk menunjukkan bahwa yang berdaulat di NKRI ini bukanlah politik 
tetapi hukum, sehingga segala persoalan kenegaraan di NKRI ini haruslah melalui dan diselesaikan secara hukum.

b. Melakukan amandemen terhadap beberapa rumusan Pasal tentang Proses impeachment Presiden dan/atau Wakil Presiden di dalam Pasal 7B Amandemen ketiga UUD NRI 1945, dengan memperjelas kekuatan hukum mengikat putusan MK, hak DPR dan wewenang MPR.

\section{DAFTAR PUSTAKA}

\section{Buku}

Fachruddin, Irfan, 2004, Pengawasan Peradilan Administrasi terhadap Tindakan Pemerintah, Bandung: PT. Alumni.

Sutiyoso, Bambang, 2006, Hukum Acara Mahkamah Konstitusi Republik Indonesia, Bandung: PT. Citra Aditya Bakti.

Thalib, Abdul Rosyid, 2006, Wewenang Mahkamah Konstitusi dan Implikasinya dalam Sistem Ketatanegaraan Republik Indonesia, Bandung: PT. Citra Aditya Bakti.

\section{Peraturan Perundang-undangan}

Undang-Undang Dasar Negara Republik Indonesia Tahun 1945.

Undang-Undang Nomor 24 Tahun 2003 tentang Mahkamah Konstitusi.

UU Nomor 27 Tahun 2009 tentang Majelis Permusyawaratan Rakyat, Dewan Perwakilan Rakyat, Dewan Perwakilan Daerah, dan Dewan Perwakilan Rakyat Daerah.

Undang-Undang Nomor 12 Tahun 2011 tentang Pembentukan Peraturan Perundang-undangan. 